\title{
Construction of Household Welfare Index and Welfare Impact of International Remittances in Rural Bangladesh
}

\section{Bezon Kumar ${ }^{1,2}$}

${ }^{1}$ Department of Economics, Rabindra University, Bangladesh, Shahjadpur, Sirajganj-6770, Bangladesh. Email: bezon.kumar3@gmail.com/ bezon.econ@rub.ac.bd; ORCID ID: 0000-0003-4489-431X

${ }^{2}$ BK School of Research, Shahjadpur, Sirajganj-6770, Bangladesh.

\section{Abstract}

This paper mainly focuses on the construction of a household welfare index to examine the welfare impact of remittances in rural Bangladesh. This paper, in achieving this objective, uses primary data and several methods. This paper constructs a household welfare index newly to measure household welfare. Besides, a linear regression and Chi-square test is used to estimate the welfare and poverty impact of international remittances, respectively. Remittance receiving households enjoy the higher level of welfare more than non-recipient households in the study area. Household welfare is augmented by 0.116 if the household is under the shade of international remittances. A significant influence of international remittances on the reduction of household poverty is also found in this study. Therefore, this paper suggests policymakers for utilizing remittances as a significant tool to improve household welfare and to reduce household poverty.

Keywords: international remittances; household welfare index; welfare; poverty; Bangladesh

\section{Introduction}

Enhancement of household welfare is a buzzword in developing countries like Bangladesh as the world, at present, ponders not only on income but also on expenditure. Household welfare depends both on the income of a household and on the standard of living, i.e. balanced improvement in consumption of food and non-food items, education, health care, housing, investment, and so on. Thus, without uplifting people's standard of living, the enhancement of welfare cannot be caged. Now, the question is what triggers people's standard of living or welfare in developing countries like Bangladesh. Previous literature states some triggering factors for household welfare and international remittance is one of them (Kangmennaang et al., 2018). According to BMET (2021), 217,669 Bangladeshis migrated abroad in 2020, while the country received US\$21,752.27 million remittances in the same year that is about 6 percent of the country's GDP. Whether and how this huge amount of remittances is contributing to the enhancement of household welfare in rural Bangladesh is yet to be studied. Furthermore, to the best of knowledge, no effective indices have been used to measure household welfare in earlier literature. Most of the researchers have used per capita household consumption expenditure or per capita household income as the dummy variable of welfare which does not interpret household welfare subtly (Raihan et al., 2009; Abbas et al., 2014; Kumar et al., 2020). In this situation, constructing an effective household 
welfare index is a must. Like the low standard of living or lower level of welfare, poverty is also one of the major issues in developing countries like Bangladesh. According to BBS (2020), in Bangladesh, about 34.3 percent of people live below the poverty line, where the rate of poverty is greater in rural areas (26.4 percent) than urban areas (18.9 percent). The majority of people in the country live in rural areas and many of them resort on inter-country migration and about 8.7 million Bangladeshi families are receiving international remittance (BBS, 2010). Thus, it is required to explore the influence of international remittances on household welfare in rural Bangladesh.

\subsection{Relationship between Remittance and Welfare}

People migrate to well-off states and remit their earnings that directly increase the level of income of their families. With that income, households meet up their daily basic needs, and invest in some productive sectors, which ultimately enhance household welfare. This mechanism is presented in Figure 1.

Figure 1. A framework of remittance and welfare enhancement

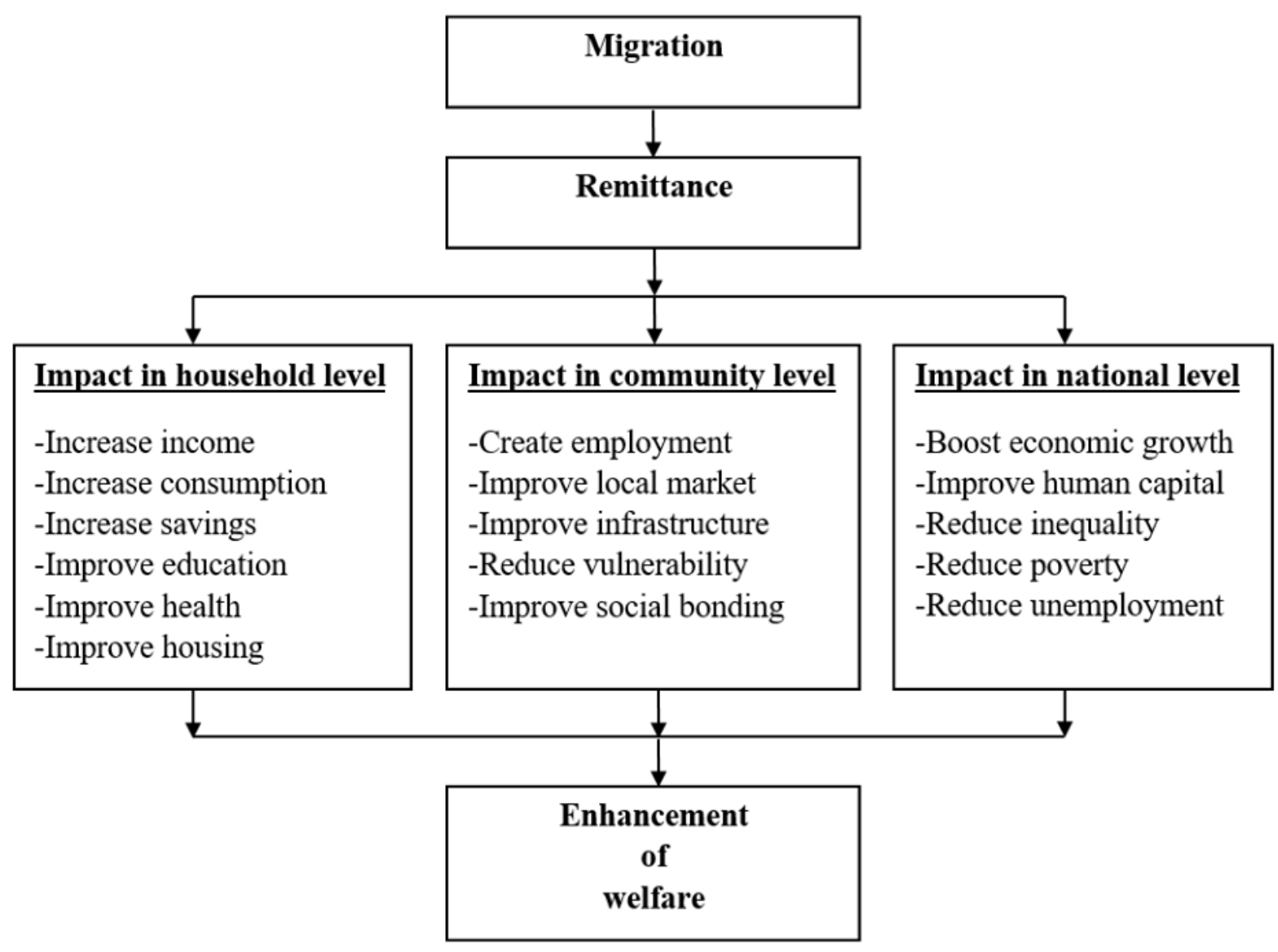

Source: Author's creation based on literature

Figure 1 indicates that migrants send remittances to their families, which affects not only the household level but also the community and national levels. At household level, remittance increases the level of income, consumption, investment or savings and improves 
health and housing condition (Kumar et al., 2018, Abbas et al., 2014). At the community level, remittance creates employment opportunities, increases the demand for local goods, and improves infrastructures and social bonding (Raihan et al., 2009) while it boosts economic growth, develops human capital, improves the balance of payments, and reduces poverty in the national level (Das, 1981 and Bruyan et al., 2005).

Figure 2. Linkage between remittances and expenditure

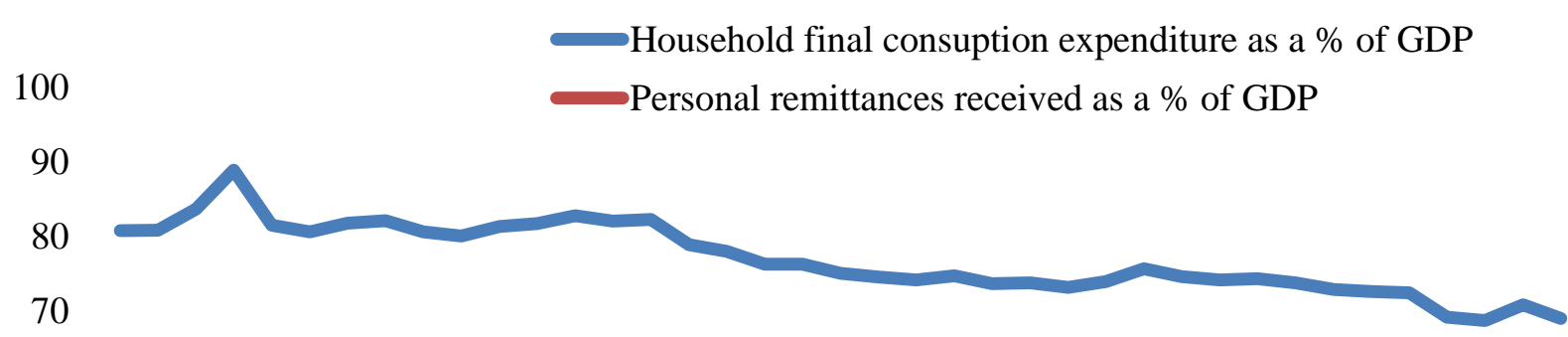

60

50

40

30

20

10

0

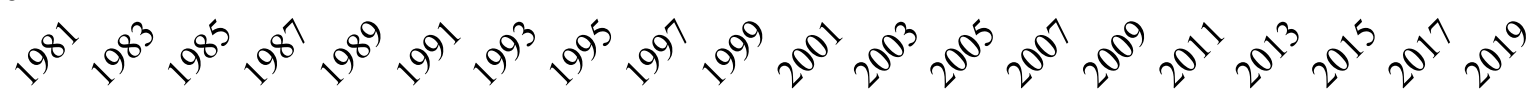

Source: World Development Indicators

The linkage between personal remittance received and household consumption expenditure od Bangladesh is stated in Figure 2. The figure reveals that the flow of both remittances and expenditure is found stable and paralel to the horizontal axis up to 1995 . Beyond that period, consumption expenditure decreases at a little bit and remittance increases. Remittance starts to fall down again after 2014. Therefore, it is found that there is no unidirectional linkage between them.

\subsection{Key Findings of Previous Literature}

By reviewing literature deliberately, it is found that earlier researchers have used different types of research methods and found different directions of association between remittances and welfare. Some researchers have found positive relations and some have found negative between them. A positive and significant impact of international remittances on household welfare is found by Nwaru et al. (2011), Etowa et al. (2015), and Akanle and Adesina (2017) while Kangmennaang et al. (2018), Fatima and Qayyum (2016) and 
Andersson (2014) found a postive relation between remittance receipt and assets accumulation of rural households. A positive and significant impact of remittances on welfare and consumer asset accumulation, especially in rural areas, but no impact on productive assets is also found. Remittance receiving households expense on consumption, health, education, vehicles, and the level of household savings largely (Thapa and Acharya, 2017 and Awan et al., 2015), thus, they enjoy a better life than remittance non-recipient households (Borici and Gavoci, 2015, and Hameli and Bytyqi, 2018). On the other hand, Cuong (2008) found an opposite direction: the impact of international remittances on income is greater than consumption expenditures, meaning that a large proportion of international remittances are used for savings and investment purposes. Javed et al. (2017) found that the effect of international remittance on food security is greater than on wealth.

Like Haider et al. (2016), Kumar (2019a) and Kumar et al. (2020), Ahmed et al. (2018) also found a positive and significant impact of international remittances on housing, drinking water and sanitation facilities, durable goods, education and nedical treatment, household economic condition, and household expenditure. Above findings shows a positive and significant relationship between international remittances and household welfare. Contrarily, Cuong and Linh (2018) found a reverse finding: migration has no effect on household welfare, meaning that if migrants do not remit in families in home countries, no effects are found on household welfare. Although remittances significantly reduce poverty (Kumar, 2019c, Abbas et al., 2014, Raihan et al., 2009) and increase consumption expenditure (Kumar, 2019a), it has no influence on education and health care (Kumar, 2019b, Wadood and Hossain, 2017 and Raihan et al., 2009).

These findings reveal that the influence of international remittances is not unidirectional which stresses to investigate a further study in the context of rural Bangladesh focusing these gaps. Therefore, the core contribution of this paper is to construct a new household welfare index to explore the welfare impact of international remittances in rural Bangladesh.

\section{Data and Materials}

\subsection{Study Area and Sample Selection}

As the study area this study selects Naogaon district because it is one of largest district in terms of migration from where a large number of workers migrate abroad every year. Using multi-stage sampling technique, Atrai and Raninagar are selected randomly among 11 upazilas. From each upazila, two unions are selected randomly whereas three villages from each union. Finally, 202 households are selected for interview and data are collected from 176 households from January to March 2020. After sorting, coding and editing of data, 168 household heads of which 84 from remittance receiving and 84 from non-receiving households are finally used for the analysis.

\subsection{Descriptive Statistics}

This study uses frequency distribution and $t$ test in analyzing the socio-economic features of respondents, and the estimated result is shown in tabular form. 


\subsection{Construction of Household Welfare Index}

Although there are some indices of measuring welfare, indices for measuring welfare in micro level is quite scant. Thus, this study focuses on this gap and constructs a new index for measuring welfare in household level following Human Development Index (HDI) stated by United Nations Development Program in 2010. This new index is named as Household Welfare Index (HWI) which is a composite statistic of per capita consumption expenditure, per capita expenditure on education, per capita expenditure on accommodation or housing, and per capita expenditure on health or medical treatment indicators. These indicators are used to rank households welfare. As this index is constructed with five indicators, five distinct indices are constructed to calculate HWI which are as follows:

$$
\text { Consumption Index }(C I)=\frac{1}{n} \sum_{i=1}^{n} \frac{\ln \left(E C_{i}\right)-\ln \left(E C_{l}\right)}{\ln \left(E C_{h}\right)-\ln \left(E C_{l}\right)}
$$

Education Index $(E I)=\frac{1}{n} \sum_{i==1}^{n} \frac{\ln \left(E E_{i}\right)-\ln \left(E E_{l}\right)}{\ln \left(E E_{h}\right)-\ln \left(E E_{l}\right)}$

$$
\text { Health Index }(H I)=\frac{1}{n} \sum_{i=1}^{n} \frac{\ln \left(E H_{i}\right)-\ln \left(E H_{l}\right)}{\ln \left(E H_{h}\right)-\ln \left(E H_{l}\right)}
$$

$$
\text { Acco modation Index }(A I)=\frac{1}{n} \sum_{i=1}^{n} \frac{\ln \left(E A_{i}\right)-\ln \left(E A_{l}\right)}{\ln \left(E A_{h}\right)-\ln \left(E A_{l}\right)}
$$

$$
\text { Investment Index }(I I)=\frac{1}{n} \sum_{i=1}^{n} \frac{\ln \left(E I_{i}\right)-\ln \left(E I_{l}\right)}{\ln \left(E I_{h}\right)-\ln \left(E I_{l}\right)}
$$

Where, $\mathrm{EC}=$ expenditure on consumption, $\mathrm{EE}=$ expenditure on education, $\mathrm{EH}=$ expenditure on health, $\mathrm{EA}=$ expenditure on accommodation, $\mathrm{EI}=$ expenditure on investment, $\mathrm{i}=$ individual household, $\mathrm{h}=$ highest value, $\mathrm{l}=$ lowest value, $\mathrm{n}=$ total number of households.

Finally, HWI is formulated with the geometric mean of above five normalized indices stated in equation 1 to 5 as follows:

$$
H W I=\sqrt[5]{C I \cdot E I \cdot H I \cdot A I . I I}
$$

A household scores higher HWI when all the indicators are higher. The value of HWI ranges from 0 to 1 . The ancestor of the index classifies households into one of three categories with respect to the value of HWI such as: 'lower level of household welfare' for HWI scores between 0 and 0.5 , 'moderate level of household welfare' for scores between 0.51 and 0.8 and 'higher level of household welfare' for scores between 0.81 and 1.0.

This study uses Household Welfare Index (HWI) to measure welfare of households. 


\subsection{Linear Regression Analysis}

To examines the welfare impact of remittances, this paper forms a linear function as follows:

$$
H W_{i}=f\left(P_{i}\right)
$$

Where, $\mathrm{HW}_{\mathrm{i}}$, dependent variable, is welfare of $\mathrm{i}^{\text {th }}$ household measured through the Household Welfare Index and $P_{i}$ is a set of independent variables. To investigate the relationship between dependent and independent variables, this study uses a multiple regression estimated through Ordinary Least Squares method because of being the dependent variable continuous following Abbas et al. (2014), Kumar et al. (2018) and Raihan et al. (2009). Econometrically the equation 7 can be formed as:

$$
H W_{i}=\delta P_{i}+\varepsilon_{i}
$$

The equation 8 simply can be written in matrix form as:

$$
\left[\begin{array}{l}
H W_{1} \\
H W_{2} \\
\vdots \\
\vdots \\
H W_{n}
\end{array}\right]_{n \times 1}=\left[\begin{array}{llllll}
1 & P_{11} & P_{21} & \ldots & \ldots & P_{n 1} \\
1 & P_{12} & P_{22} & \ldots & \ldots & P_{n 2} \\
\vdots & \vdots & \vdots & \ldots & \ldots & \vdots \\
\vdots & \vdots & \vdots & \ldots & \ldots & \vdots \\
1 & P_{1 n} & P_{2 n} & \ldots & \ldots & P_{n n}
\end{array}\right]_{n \times k}\left[\begin{array}{l}
\delta_{1} \\
\delta_{2} \\
\vdots \\
\vdots \\
\delta_{n}
\end{array}\right]_{k \times 1}+\left[\begin{array}{l}
\varepsilon_{1} \\
\varepsilon_{2} \\
\vdots \\
\vdots \\
\varepsilon_{n}
\end{array}\right]_{n \times 1}
$$

Therefore, the specified multiple regression model can be written as:

$$
\begin{aligned}
H W_{i}= & \delta_{0}+\delta_{1} A G+\delta_{2} S E+\delta_{3} E D+\delta_{4} H S+\delta_{5} O C+\delta_{6} L S \\
& +\delta_{7} R E+\delta_{8} P I+\varepsilon_{i}
\end{aligned}
$$

where, $\delta_{0} \ldots . \delta_{8}$ are parameters and $\epsilon_{\mathrm{i}}$ is the error term. The independent variables used in regression function are described in Table 1.

Table 1. Explanation of independent variables included in regression function

\begin{tabular}{llll}
\hline Variables & Type & Measurement Procedure & $\begin{array}{c}\text { Expected } \\
\text { Sign }\end{array}$ \\
\hline $\begin{array}{l}\text { Age (AG) } \\
\text { Sex (SE) }\end{array}$ & $\begin{array}{l}\text { Continuous } \\
\text { Dummy }\end{array}$ & $\begin{array}{l}\text { Age of household head (years) } \\
(1 \text { if the household head is female and } 0, \\
\text { otherwise })\end{array}$ & - \\
$\begin{array}{l}\text { Education (ED) } \\
\text { Household size } \\
\text { (HS) }\end{array}$ & $\begin{array}{l}\text { Continuous } \\
\text { Cccupation (OC) }\end{array}$ & $\begin{array}{l}\text { Schooling years of household head } \\
\text { Total number of persons in the family }\end{array}$ & + \\
& Dummy & $\begin{array}{l}1 \text { if the occupation of household head is } \\
\text { non-agriculture, } 0 \text { otherwise }\end{array}$
\end{tabular}


Land size (LS) Continuous Total quantity of cultivable land of the + household (bigha $=33.33$ decimals)

Remittance (RE) Dummy 1 if the household receives international + remittances, 0 otherwise

Per capita income Continuous Per capita income of the household + (PI) (Tk./month)

Table 2. Mean difference of socioeconomic features of respondents

\begin{tabular}{llllll}
\hline Variable & $\begin{array}{l}\text { Remittance } \\
\text { receiving (1) }\end{array}$ & $\begin{array}{l}\text { Remittance } \\
\text { non-receiving (2) }\end{array}$ & $\begin{array}{l}\text { Mean } \\
\text { Difference (1-2) }\end{array}$ & $\mathrm{t}$ & Sig. \\
\hline Age & 46.01 & 42.74 & 3.27 & 1.66 & 0.09 \\
Sex & 0.70 & 0.81 & -0.11 & -1.62 & 0.10 \\
Education & 6.46 & 4.69 & 1.77 & 2.57 & 0.01 \\
Household size & 4.73 & 4.51 & 0.21 & 0.88 & 0.38 \\
Land & 5.09 & 2.96 & 2.13 & 3.71 & 0.00 \\
Per capita income & 10554.42 & 3904.72 & 6649.70 & 5.43 & 0.00 \\
Per capita expenditure & 58136.89 & 19205.85 & 38931.04 & 6.34 & 0.00 \\
Welfare & 0.48 & 0.32 & 0.16 & 8.16 & 0.00 \\
\hline
\end{tabular}

\subsection{Chi-Square Test}

Pearson's Chi-Square test is used to examine the poverty impact of remittances. In this case, headcount poverty index is used to measure the poverty status of households and Tk.2925 is considered as poverty line following the declaration of World Bank in 2010 (\$1.12 daily per capita income). Chi-Square test is performed with respect to the following hypothesis:

Null Hypothesis $\left(\mathrm{H}_{0}\right)$ : International remittances have no impact on household poverty.

Alternative Hypothesis $\left(\mathrm{H}_{1}\right)$ : International remittances have impact on household poverty.

\section{Results and Discussion}

\subsection{Socio-economic Features of the Households}

Socio-economic features of households are measured through $t$ test and the estimated findings is shown in Table 2 .

Source: Field survey, 2020

Table 2 shows the mean value and mean difference, tested by $\mathrm{t}$ test, of some socio-economic charecteristics of the households who received remittances and who did not. A significant mean difference of age is found between remittance receiving (46.01 years) and non-receiving (42.74 years) households. Education, land, per capita income, per capita expenditure, and welfare are also statistical significant while household size is not statistically significant. 


\begin{tabular}{|c|c|c|c|c|c|c|c|c|}
\hline \multirow{2}{*}{\multicolumn{2}{|c|}{ Sectors }} & \multicolumn{2}{|c|}{$\begin{array}{l}\text { Remittance } \\
\text { receiving (1) }\end{array}$} & \multicolumn{2}{|c|}{$\begin{array}{l}\text { Remittance } \\
\text { non-receiving (2) }\end{array}$} & \multirow{2}{*}{$\begin{array}{l}\text { Mean } \\
\text { Difference } \\
(1-2)\end{array}$} & \multirow[b]{2}{*}{$\mathrm{t}$} & \multirow[b]{2}{*}{ Sig. } \\
\hline & & Mean (1) & $\%$ & Mean (2) & $\%$ & & & \\
\hline $\begin{array}{l}\text { Food } \\
\text { non-food }\end{array}$ & and & 39744.28 & 68.36 & 12902.33 & 67.18 & 26841.95 & 4.81 & 0.00 \\
\hline Housing & & 12614.97 & 21.70 & 1990.96 & 10.37 & 10624.01 & 6.28 & 0.00 \\
\hline Education & & 2385.61 & 4.10 & 2856.97 & 14.88 & -471.36 & -0.76 & 0.45 \\
\hline Health & & 1552.96 & 2.67 & 1058.88 & 5.51 & 494.08 & 2.11 & 0.00 \\
\hline Investment & & 1839.08 & 3.16 & 396.71 & 2.07 & 1442.37 & 13.02 & 0.00 \\
\hline Total & & 58136.89 & 100 & 19205.85 & 100 & 38931.04 & 6.34 & 0.00 \\
\hline
\end{tabular}

Source: Field survey, 2020

\subsection{Per Capita Household Expenditure}

Per capita household expenditure on food and non-food items, housing, education, health, and investments are analyzed through $t$ test and the finding is presented in Table 3.

Table 3. Per capita household expenditure in different sectors (Tk./year)

Remittance receiving households expense Tk.58136.89 as the gross per capita household expenditure while non-receiving households expense Tk.19205.85, and this statistically significant difference reveals that remittance receiving households enjoy the better level of welfare or the higher level of quality life than non-receiving households. Remittance receiving households expense mostly (68.36 percent of gross expenditure) in consumption of food and non-food purposes (consumption and stationary products, clothing and shoes, travelling and entertainment, utility bills, and so on) than non-receiving households (67.18 percent). Although this difference is too small, it is statistical significant. Besides, remittance recipient households expense lowest in investment purpose (3.26 percent) whereas it is 2.07 percent for non-recipients. This finding interprets that both types of households expense very few in productive purposes that would create new employment opportunities. Table 3 also shows that remittance receiving households expense more than remittance non-receiving households in all purposes except education, which interprets no influence of remittances on education.

\subsection{Results of Household Welfare Index}

Welfare of both the households who received remittances and who did not is measured through Household Welfare Index (HWI), and the finding is presented in the following figure. 
Figure 3. Value of household welfare index

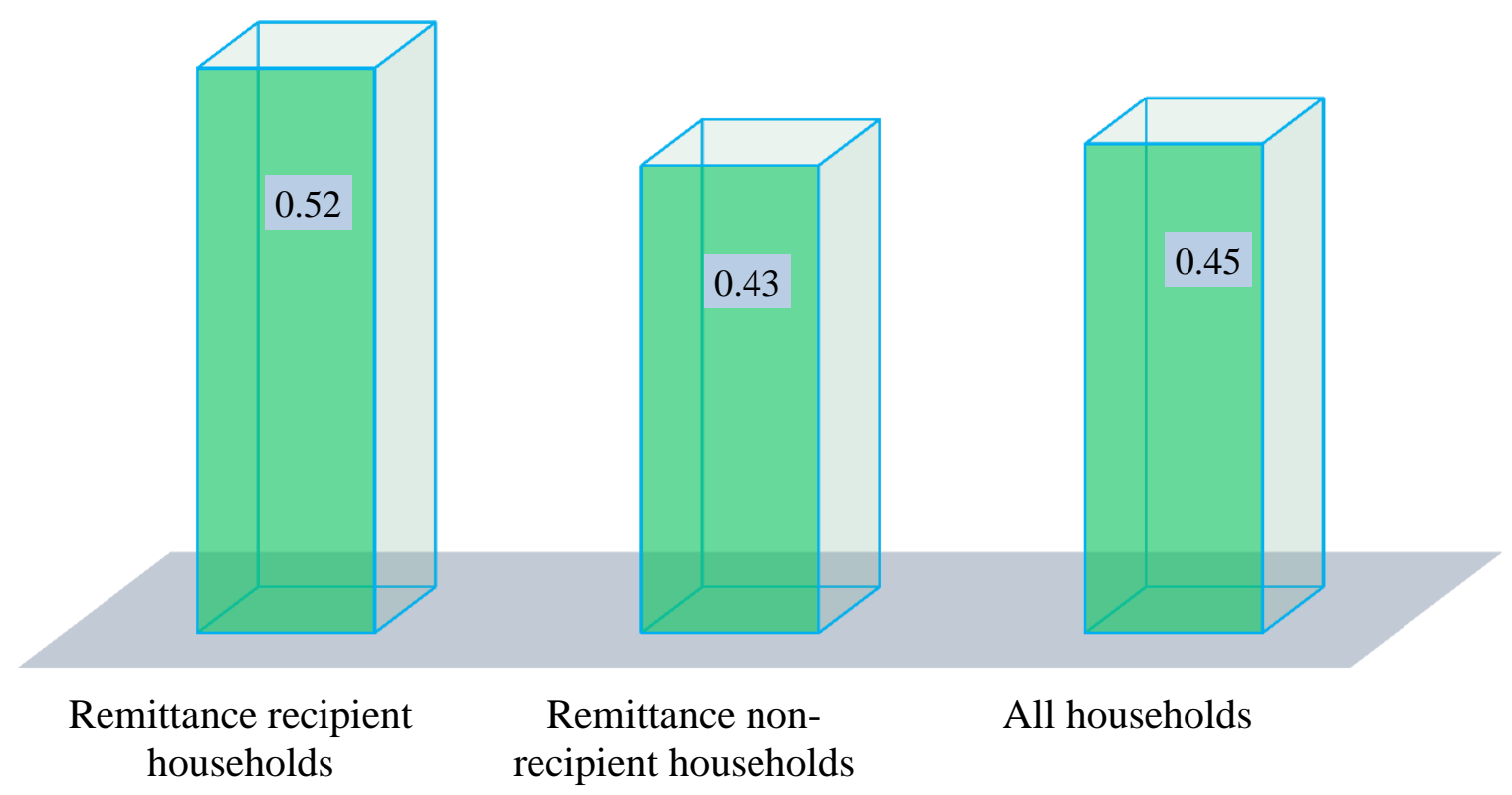

Source: Field survey, 2020

\begin{tabular}{lccc}
\hline \multirow{2}{*}{ Level of welfare } & \multicolumn{2}{c}{ Households in percentage } & \\
\cline { 2 - 4 } & $\begin{array}{c}\text { Remittance } \\
\text { receiving }\end{array}$ & $\begin{array}{l}\text { Remittance } \\
\text { non-reeiving }\end{array}$ & All \\
\hline Lower & 55.95 & 73.81 & 72.02 \\
Moderate & 44.05 & 26.19 & 27.98 \\
Higher & - & - & - \\
\hline Total & 100 & 100 & 100 \\
\hline
\end{tabular}

Source: Field survey, 2020

This study finds the the value of welfare of remittance receiving households by 0.52 and remittance non-receiving households by 0.43 . This interprets that households who received remittance enjoy a moderate level of welfare and households who did not receive remittance enjoy the lower level of welfare. Besides, a lower level of welfare (0.45) for all households is found in the study area. From this analysis, a significant impact of remittances is found on welfare in the study area.

The level of household welfare (lower, moderate, and higher) of both remittance receiving and non-receiving households is presented in Table 4.

Table 4. Distribution of household by the level of welfare

Source: Field survey, 2020

Table 4 represents that 72.02 percent households enjoy the lower level of welfare while 27.98 percent households enjoy a moderate level of welfare in the study area. An interesting finding is found from the analysis that the rate of households enjoyed moderate level of welfare is larger for remittance receiving group (44.05 percent) than non-receiving group 
(26.19 percent) although a big portion of households of both group of households enjoy the lower level of welfare. A shocking finding is that no household enjoys the higher level of welfare in the study area. Therefore, it is clear that international remittances have a positive influence on household welfare.

\subsection{Results of the Regression Model}

In measuring the welfare impact of remittances, a linear regression model is used. This is analyzed with Stata14.2 and the result is displayed in Table 5.

Table 5. Result of the linear regression model

\begin{tabular}{lllll}
\hline Variables & Coefficient & Robust std. Err. & t-ratio & $\mathrm{P}>|\mathrm{t}|$ \\
\hline Cons. & 0.3310 & 0.0432 & 7.67 & 0.000 \\
Age & 0.0004 & 0.0009 & 0.42 & 0.674 \\
Sex & -0.0217 & 0.0212 & -1.03 & 0.307 \\
Education*** & 0.0060 & 0.0022 & 2.75 & 0.007 \\
Household size $* * *$ & -0.0186 & 0.0053 & -3.53 & 0.001 \\
Occupation** & 0.0370 & 0.0192 & 1.92 & 0.056 \\
Land*** & 0.0096 & 0.0021 & 4.49 & 0.000 \\
Remittance*** & 0.1116 & 0.0212 & 5.27 & 0.000 \\
Per capita income* & 0.000002 & 0.0000012 & 1.82 & 0.071 \\
\hline $\mathrm{F}(8,159)=25.39 ;$ Prob $>\mathrm{F}=0.000 ; R^{2}=0.4921$, Root MSE $=0.10705 ; \mathrm{DW}=1.85$ \\
Note: $* * * * *$ and $* 1 \%, 5 \%$ and $10 \%$ level of significance. \\
\hline \multicolumn{4}{l}{}
\end{tabular}

Source: Field survey, 2020

The value of $R^{2}$ (0.4921) indicates that regressors explain regresand by 50 percent. On the other hand, F-statistic, 25.39 (prob $>\mathrm{F}=0.000$ ), reveals the complete goodness of fit of the model. During the time of analysis, it is found that data were not incurred with any heteroscedasticity problem. Moreover, robust standard error action was taken. This paper also exercised Variance Inflation Factors (VIF) in detecting multicollinearity and found a negative result. This paper also tested autocorrelation by Durbin-Watson test and found a negative outcome, shown by the value of DW (1.85). Education, household size, occupation, land, remittance, and per capita income are found as significant variables.

The findnings of this study indicates that household welfare increases by 0.0060 if household head's schooling is increased by one year. This finding interpreted by a way that highly educated household head are more conscious of standard of living which enhances household welfare. This finding is in line with Kumar (2019b).

This paper finds a negative and significant association between household size and welfare. Household welfare decreases by 0.0186 when the family member is increased by one. The rational explanation may be that a household with large household size means large dependency ratio which declines per capita household expenditure, hence welfare decreased. Kumar et al. (2020) also found the similar findings. 
When household head's occupation becomes non-agricultural, welfare is increased by 0.0370 , which is significant at 5 percent significance level. The findings can be interpreted in a way that people can earn more income from non-agricultural ocupations than agriculture. By this way the level of household welfare is enhanced. This finding is as similar as Abbas et al. (2014).

Similarly, a significant relationship is found between land size and welfare, i.e, welfare increases by 0.0096 when a household acquires a one Bigha of land. Large size of land holder households can produce crops, spieces, vegetables, poultries, fisheries, livestock, forestry, and so on that results a handsome amonut income or welfare. Kumar et al. (2020) and Abbas, et al. (2014) found the similar finding.

The value of household welfare increases by 0.1116 as a result of receving remittance by a household. Remittance receving households can meet up their needs easily with remittance, and can also invest in productive sectors which generates employment and earning opportunities and reduces poverty. By this way international remittances enhance the household welfare. Similar result is found by Wadood and Hossain (2017) and Nawru et al. (2011).

The value of household welfare will be increased by 0.000002 if the per capita income of a household is increased by one Taka. This finding is significant at 10 percent significance level and can be explained in a way that high income households can expense as many as they have in meeting up their needs, results the enhance ment of household welfare. Abbas et al. (2014) and Raihan et al. (2009) also go with this finding.

\subsection{Result of Chi-Square Test}

Chi-Square test for examining the poverty impact of international remittances is analyzed through SPSS 23 and the estimated finding is shown in Table 6.

Table 6. Results of Chi-square test

\begin{tabular}{llll}
\hline Category & Remittance non-recipient & Remittance recipient & Total \\
\hline Poor & $54(29.5)$ & $5(29.5)$ & $59(59)$ \\
Non-poor & $30(54.5)$ & $79(54.5)$ & $109(109)$ \\
\hline Total & $84(84)$ & $84(84)$ & $168(168)$ \\
\hline
\end{tabular}

Pearson's Chi-Square Value $=62.722(0.000)$; Expected frequencies are given in parenthesis

Source: Field survey, 2020

Table 6 shows that among 84 remittances recipient households, only 5 households are poor while 79 households are non-poor. On the other hand, 54 households are poor and 30 households are non-poor among 84 remittance non-receiving households. This difference is crosstab checked by Pearson Chi-Square test and the test is statistically significant at 1 percent level of significance. This reveals a statistically significant relationship between remittances and poverty reduction in such a way that remittance receiving households are involved in different productive activities like business, farming, investment in banks, buying lands, and so on that increase their per capita household income and reduce poverty. This 
finding allies to Kumar (2019a), Abbas et al. (2014), Kumar (2019c), and Raihan et al. (2009).

\section{Conclusions}

This paper mainly investigated three distinct research problems: comparative levels of household welfare of both remittances receiving and non-receiving households; household welfare and poverty impact of international remittances. To elaborate these questions with some interesting findings, I used primary data and several methods.

First, I found the moderate ( 0.45 ) level of household welfare aggregately in the study area. I also found that welfare is highly enjoyed by the remittance receiving households than the non-receiving households. Second, I found that welfare increases by 0.116 when a household receives international remittances. Finally, I found a statistically significant impact of remittances on poverty reduction.

Therefore, this study suggests policymakers for taking policies which are beneficial for receiving more remittance and for utilizing remittances in productive purposes so that it may help in enhancing welfare and reducing poverty. The author of this paper expects that the findings of this study may be beneficial to the policymakers and remittance recipient households in receiving more remittances and utilizing remittances in productive purposes.

\section{Acknowledgement}

Although this research did not received any grants or financial supports from any organizations, author of this research duly acknowledge the technical facilities provided by BK School of Research.

\section{Conflict of Interest}

There is no conflict of interest. .

\section{Data Availability}

Data is added online as supplementary file. It will also be provided on request.

\section{References}

Abbas, K., Sabir, H. M., Shehzadi, A., and Abbas, Q. (2014). Impact of Workers' Remittances on Household Welfare in District Jhang (A Case Study of Tehsil 18 Hazari). Journal of Finance and Economics, 2(4), 131-135. Doi: 10.12691/jfe-2-4-5.

Ahmed, R., Saha, J. K., Begum, M. and Haque, M. S. (2018). Impact of foreign remittances on household welfare in Sylhet Region of Bangladesh. Journal of Business and Economic Management, 6(2): 22-32.

Akanle, O. and Adesina, J. O. (2017). Remittances and household welfare in Nigeria. African Population Studies, 31(1): 3194-3211.

Andersson, L. (2014). Migration, remittances and household welfare in Ethiopia. UNU working paper. ISSN 1871-9872.

Awan, M. S., Javed, M. and Waqas, M. (2015). Migration, remittances, and household welfare: evidence from Pakistan. The Lahore Journal of Economics, 20(1): 47-69. 
BBS. (2010). Household Income and Expenditure Survey 2010. Dhaka: Bangladesh Bureau of Statistics (BBS). Available at: http://catalog.ihsn.org/index.php/catalog/2257.

BBS. (2020). Bangladesh Economic Review 2020. Ministry of Finance, Government of Bangladesh.

Available

at: https://mof.portal.gov.bd/site/page/28ba57f5-59ff-4426-970a-bf014242179e/Banglades h-Economic-Review-2020.

BMET. (2021). Overseas employment and remittances (1976 to 2020). Available at: http://www.old.bmet.gov.bd/BMET/viewStatReport.action?reportnumber=16.

Borici, A. and Gavoci, M. (2015). The impact of remittances on households' well-being: evidence from Albania. International Journal of Economics, Commerce and Management, 3(11): 80-103.

Bruyn, D. T. (2005). Dynamics of Remittance Utilization in Bangladesh. IOM Migration Research Series, No. 18, UN, New York, Available at: https://doi.org/10.18356/e227e838-en.

Cuong, N. V. (2008). Impacts of international and internal remittances on household welfare: evidence from Vietnam. Asia-Pacific Journal of Rural Development, 16(1): 59-92. doi: 10.18356/35fbb4fa-en.

Cuong, N. V. and Linh, V. H. (2018). The Impact of migration and remittances on household welfare: evidence from Vietnam. International Migration and Integration, 19(4): 945-963. https://doi.org/10.1007/s12134-018-0571-3.

Das. H. K. (1981), Impact of Migration and Money Remittances on the Economy of Developing Nations (A case Study of Bangladesh), Journal of the Institute of Bankers Bangladesh, 13: 57-69, Dhaka.

Etowa, E. B., Nweze, N. J. and Arene, C. J. (2015). Effects of migrant remittances on farm household welfare in Nigeria. Review of Agricultural and Applied Economics, 18(1): 3-10. doi: 10.15414/raae.2015.18.01.03-10.

Fatima, K. and Qayyum, A. (2016). Analyzing the effect of remittances on rural household in Pakistan. Turkish Economic Review, 3(2): 292-299.

Haider, M. Z., Hossain, T. and Siddiqui, O. I. (2016). Impact of remittance on consumption and savings behavior in rural areas of Bangladesh. Journal of Business, 1(4): 25-34. http://journalofbusiness.us

Hameli, K. and Bytyqi, Q. (2018). The impact of remittances on households: the case with residents of the Prizren region. Prizren Social Science Journal, 2(2): 1-11.

Javed, M., Awan, M. S. and Waqas, M. (2017). International migration, remittances inflow and household welfare: an intra-village comparison from Pakistan. Social Indicators Research, 130(2):

779-797. https://link.springer.com/article/10.1007/s11205-015-1199-8.

Kangmennaang, J., Bezner-Kerr, R. and Luginaah. (2018). Impact of migration and remittances on household welfare among rural households in Northern and Central Malawi. Migration and Development, 7(1): 55-71. https://doi.org/10.1080/21632324.2017.1325551 
Kumar, B. (2019a). Remittances, poverty and welfare: Evidence from Cumilla, Bangladesh. American Journal of Data Mining and Knowledge Discovery, 4(1): 46-52. doi:10.11648/j.ajdmkd.20190401.17.

Kumar, B. (2019b). The impact of international remittances education and health in Bangladesh. International Journal of Science and Qualitative Analysis, 5(1): 6-14. doi:10.11648/j.ijsqa.20190501.12.

Kumar, B. (2019c). The impact of international remittances on poverty alleviation in Bangladesh. Remittances Review, 4(1): 67-86. doi:10.33182/rr.v4i1.665.

Kumar, B., Ali, S. R. and Kibria, M. G. (2020). International remittances, household welfare, and women empowerment: evidence from Bangladesh. Women Empowerment and Well-Being for Inclusive Economic Growth. 174-190. Available at: https://www.igi-global.com/chapter/international-remittances-household-welfare-and-w omen-empowerment/265667.

Kumar, B., Hossain, M. E. and Osmani, M. A. G. (2018). Utilization of international remittances in Bangladesh. Remittances Review, 3(1): 5-18, Available at: https://journal.tplondon.com/ index.php/rem/article/view/986/694.

Nwaru, J. C., Iheke, O. R. and Onyenweaku, C. E. (2011). Impact of migrant remittances on the welfare of arable crop farm households in South Eastern Nigeria. Human Ecology Review, 18(2): 159-166.

Raihan, S., Khondker, B. H., Sugiyarto, G. and Jha, S. (2009). Remittances and household welfare: a case study of Bangladesh. ADB Economics Working Paper-189.

Thapa, S. and Acharya, S. (2017). Remittances and household expenditure in Nepal: evidence from cross-section data. Economies, 5(16): 1-17. doi:10.3390/economies5020016.

Wadood, S. N. and Hossain, A. (2017). Microeconomic impact of remittances on household welfare: evidence from Bangladesh. Business and Economic Horizons, 13(1): 10-29. https://ideas.repec.org/a/pdc/jrnbeh/v13y2017i1p10-29.html. 